\title{
Editorial
}

\section{Place branding: Dilemma or reconciliation between political ideology and economic pragmatism?}

\author{
Place Branding and Public Diplomacy (2007) 3, 3-7. doi:10.1057/palgrave.pb.6000053
}

In the last half-century, the presence of the state in many sectors and industries has shrunk dramatically. During this period, many liberal thinkers, who stood in defence of oversized states and resisted measures such as privatisation, witnessed the increasing deregulation of strategic industries, such as banking, transportation, telecommunications and energy. They also saw the migration of most communist and socialist regimes to free-market economic systems and the redefinition of the state's role in the new economy. Even left-wing and progressive chiefs of state started to veer away from practices such as protectionism, trade barriers and subsidies, formerly defended and carried out on behalf of 'national interest'.

In spite of the trend towards economic liberalisation and pragmatism, the proposition of employing tools pervasively used in the promotion of businesses, products and services to promote places still puzzles some liberal minds.

Irrespective of this pervasive and documented change, some resist the idea of countries as products, brands and beyond advocated by some scholars and practitioners (Kotler and Gertner, 2002).

Does place branding really pose a dilemma between political ideology and economic pragmatism, as some seem to believe? Instead, would place branding not provide an opportunity to reconcile the supposed conflict between the two ideas, especially for image-troubled places?

\section{THE NEW GEOGRAPHY OF AN INEQUITABLE WORLD}

Geography has changed more and faster than a student sitting on school bench a few decades ago could ever imagine. By 2006 , more than 6.5 billion people lived in 243 countries around the world. Of these, 202 are sovereign states and 192 of them are nations represented at the United Nations (Wikipedia, 2006). Just a few of the world's nations are well-off places with familiar names that appeal to global audiences. Countries that emerged as autonomous nations rather recently form a noticeably larger set. This group comprises 15 states that previously formed the Soviet Union, five new sovereign states that formed Yugoslavia and a small group of states that recently declared their independence (Country Watch, 2006). Most of these nations remain unknown for a massive number of people in the world.

Regretfully, inequality continues to prevail in this fast-changing world. A study released by the United Nations Institute at the end of 2006 revealed that the richest 2 per cent of adults hold more than half of the world's wealth. At the opposite side of the spectrum, half of the 
world's population barely owns 1 per cent of the world's wealth (BBC News, 2006). Nearly half of the world's population lives in poverty, with less than $\$ 2$ a day, and more than one billion people in the world are in extreme poverty, with an income below $\$ 1$ a day (Thinkquest, 2006).

How can these disparities be resolved? The vast majority of the world's countries are enormously deprived of economic wealth. In most cases, their names remain unheard of to the majority of the world's inhabitants. Many of them are emerging, newly industrialised or in transition economies struggling to compete in world markets. What can strategic marketing and branding do for them?

\section{THE CHALLENGE OF BRANDING TROUBLED IMAGED PLACES}

Positive brand images have helped many economies boost their exports and attract investments, businesses, factories, visitors, residents and talented people. On the other hand, an uncountable number of places continue to be unfamiliar to consumers. Many are known, but have image problems that impair their ability to compete in the market place. In some cases, these images are based on inaccurate information or widespread stereotypes recurrently reinforced by the media and the entertainment industry. In other instances, these images are founded on past episodes of political unrest, natural disasters, violence and economic downturns. Place images may be clouded by these occurrences much longer than it takes to overcome or correct the problems depicted.

Place image problems can manifest themselves in different ways. In some instances, the branding task is not obviously built upon negative attributes, but rather on an unappealing image. Such is the case of Greenland, mostly perceived as a frozen and harsh environment distant from the rest of the world. The Branding Greenland Group took the task of 'defrosting' Greenland's image (Ray, 2006). Currently 85 per cent of visitors come from Denmark. The objective is to extend the customer base, motivating more people to learn about Greenland and act on a desire to visit it.

Israel is another country that is trying to reshape its image. Most of the nation's image has been determined by the media coverage of the Israeli-Palestinian conflict in the last 30 years. Amir Reshef-Gissin, director of the Israeli Foreign Ministry's Public Affairs Department, laments that in Europe the country is perceived as 'an aggressive, religious, intolerant society' (Friedman, 2006). In 2006, recognising the need to further tourism, investment and exports, the Foreign Ministry invited advertising and branding practitioners and academics to discuss a brand concept for the country.

Another type of brand problem concerns countries that have great assets that cannot be properly marketed due to image problems. Such is the case, for example, of Victoria Falls, the largest curtain of water in the world, located between Zambia and Zimbabwe. While Zambia's tourism receipts have quintupled in a decade, travel warnings about the risks involved have kept tourists from visiting Zimbabwe, in spite of the Falls' lure (Wines, 2006).

There are many countries in the world so impoverished that the image task is not so much to build positive associations with their names, but rather to call the world's attention to their predicaments. Such is the case with places that have experienced genocides, such as Rwanda in the 1990s and more recently, Darfur, in Sudan. Lately, celebrities such as movie stars and rock bandleaders have helped raise awareness about acute humanitarian crises in different parts of the globe. These nations are at a stage where brand awareness is needed not in order to promote exports or attract investments and tourists, but rather to draw crucial aid.

Managing place brands also seems to be an immense challenge for emerging, newly industrialised and transitioning nations, including those that shifted from socialist to free-market economic systems. Unfortunately, this scenario is common and afflicts places across vast regions of the world, such as Latin America, Eastern Europe, Africa and Asia. While a few places have succeeded in overcoming 
their image problems and have enhanced the equity of their brand names, others still struggle in the pursuit of economic development.

\section{THE WORLD'S PURSUIT FOR ECONOMIC DEVELOPMENT}

One may argue that, in a vast number of cases, a country's economic growth benefits just a few corporations and a small minority of already affluent citizens. As a result, economic growth can potentially widen the gap between the rich and poor segments of a society. Nevertheless, economic development, prosperity and social justice are among most nations' governing objectives. They are still sought-after goals for most states in the world, from the smallest and most destitute to the largest and wealthiest ones.

In recent decades, improvements in communication and transportation technologies have intensified competition in areas that directly affect income, economic growth, employment, infrastructure and services, such as tourism, investment and business attraction, events and exports. The Internet has allowed tiny communities located in remote areas of the planet to compete with much larger and resourceful places for markets, opportunities and resources that are relatively scarce in the world.

Economic development has transcended the purview of public policy and has become a paramount market challenge for places.

Numerous communities, cities, states, nations and regions around the world have already understood the urgency of developing and promoting some sort of competitive advantage. Towards this goal, places are increasingly adopting strategic marketing and brand management concepts and tools to succeed in the new economy.

According to Simon Anholt, 'Place branding is the management of place image through strategic innovation and coordinated economic, commercial, social, cultural and government policy' (interview, January 2007). 'Competitive Identity (or CI) is the term I [Anholt] use to describe the synthesis of brand management with public diplomacy and with trade, investment, tourism and export promotion.'

(Anholt, 2007).

In such a fiercely competitive arena, successful places must understand the needs and wants of specific target markets and find ways to satisfy them more efficiently and effectively than its place competitors. To accomplish it, they have to implement concepts and tools long adopted by firms, organisations, groups and individuals in similarly competitive environments.

\section{BALANCING POLITICS AND BUSINESS}

A number of emerging economies are already pursuing a balance between ideology and pragmatism. States of all sizes and levels of economic development have adopted strategic marketing. Cuba, for example, one of the few remaining socialist regimes in the world, uses advertising and other marketing extensively to compete with its Caribbean neighbours and other nations for investments and visitors, just as corporations do.

There are myriad examples of all types of countries using place marketing and branding to support economic development.

Professionalism, perseverance and long commitment are common traits of thriving experiences. For example, IDA Ireland, the Industrial Development Agency, was founded in 1949 , more than half a century ago. By 2006, it had attracted 1,050 companies to invest in the country, with the support of 13 offices around the world (IDA, 2006). Over the years, Ireland has gradually overcome an image defined by unemployment, decadence, violence and conflict, to become a prime destination for investments in Europe.

Another remarkable example took place in Central America after Costa Rica's president visited Intel's headquarters in the United States. In 1994, Costa Rica, competing with much larger countries, such as Argentina, Brazil and Mexico, attracted an Intel microprocessor plant, an investment worth $\$ 550 \mathrm{~m}$. Costa Rica's investment promotion agency, CINDE, coordinated the bid for Intel's investment. Other 
agencies across Latin America and the Caribbean have done a worthy job marketing and branding their countries, such as Chile's CORFO, Colombia's COINVERTIR, Jamaica's JAMPRO, El Salvador's PROESA, Mexico's BANCOMEXT and Cuba's CPI. In many cases, these agencies employ experienced marketing and branding managers, benchmark other experiences and hire consultants to help them. They monitor the external environment, understand their competitive environment and are constantly reviewing their marketing objectives and strategies.

The world's two largest emerging economies, China and India, also provide notable examples of the combination of politics and marketing, branding and sales practices. Together, these countries are home to approximately a third of the world's population.

In April 2006, General Secretary of the Communist Party of China and President of the People's Republic of China Hu Jintao visited the USA. The American press and news agencies stressed the fact that 'the welcome to the United States would not be hosted by President Bush, or Secretary Rice, or other government officials' (Economic Trends, 2006). Indeed, on his way to Washington, DC to meet President George W. Bush, President Hu Jintao landed in Seattle, Washington State, where Microsoft's CEO Bill Gates greeted him. Before continuing his trip to the US capital, President $\mathrm{Hu}$ Jintao visited Microsoft's headquarters and had dinner at Bill and Melinda Gates' residence, also attended by CEOs of other important global corporations.

Similarly, India's Information and Technology Minister Dayanidi Maran has met titans of the corporate world, such as Microsoft's Bill Gates, Cisco's John Chambers and Intel's Craig Barret, to discuss how these companies and the country could collaborate. As a result, foreign investments in India's high-tech sector have totalled billions of dollars, driving the country to a leading position in information technology.

China and India are consistently featured in cover articles of the world's most important business and magazines. Even though some of these articles touch on enduring political and social problems, the extraordinary growth rates and transformation of these countries are generally the focus of these reports. Recurrently, analysts argue that in the 21st century, China and India will have the economic importance that the US had in the 20th century. Politicians and administrators seem to understand that these articles constitute great opportunities to add value to the countries' brands and enhance their equity among prospective investors and visitors. The fact that they stress positive aspects of the country does not necessarily mean that they are unaware or unconcerned about national problems.

Pankaj Mishra, author of 'Temptations of the West: How to Be Modern in India, Pakistan, Tibet and Beyond', argues that various serious problems facing India will not be straightened out by complacent myths about a new India. He writes, 'But the increasingly common, business-centric view of India suppresses more facts than it reveals. Recent accounts of the alleged rise of India barely mention the fact that the country's $\$ 728$ per capita gross domestic product is just slightly higher than that of sub-Saharan Africa and that, as the 2005 United Nations Human Development Report puts it, even if it sustains its current high growth rates, India will not catch up with high-income countries until 2106' (Mishra, 2006).

Place branding is certainly not a panacea, a universal remedy for all the problems a country faces. Every time a country name is mentioned, there is, however, an opportunity to add or subtract value to its equity, possibly helping it to achieve economic development.

\section{CONCLUSIONS}

Is it possible for ideology to be the sole animus of societal change, given the drastic social, political, economic, legal, cultural and technological changes that have taken place in the last century, and in face of the severe competitions existing among regions, nations and cities around the world? Would it not be necessary to reconcile political ideology and 
pragmatism in the new economy and competitive environments faced by nations?

Scores of nations around the world have grasped the need to be market- and customeroriented as a way to attract investments, industries, visitors and residents, and therefore achieve their paramount goals of economic development. Public administrators and politicians need to understand their redefined roles in the new economy. They must learn and develop new skills to adjust to a market- and customer-oriented approach to social and economic development.

Many already understand the need to manage a country's name as a brand that can add to or subtract from the perceived value of a country's products. There is no clash between pursuing growth, prosperity and social justice and the adoption of marketing and branding concepts and practices. These tools can be especially beneficial for emerging, newly industrialised and transitional nations struggling to succeed in an increasingly competitive marketplace. Therefore, place branding should be perceived as an effective way to reconcile ideology and economic pragmatism.

\section{David Gertner Associate Professor of Marketing Lubin School of Business, Pace University, NY, USA}

\section{References}

Anholt, S. (2007) 'Competitive Identity', Palgrave Macmillan, London, UK.

BBC News (2006) in http://news.bbc.co.uk/1/hi/business/ 6211250.stm, viewed on 11th December, 2006.

Country Watch (2006) in http://www.countrywatch.com/ facts $/$ facts_default.aspx?type $=$ text $\&$ topic $=$ SENEWviewed on 11th December, 2006.

Economic Trends (2006). Hu Jintao Visit: 'Bill Gates as Britney Spears.' Published on Monday, 17th April, 2006, in http:// economictrends.blogspot.com/2006/04/hu-jintao-visitbill-gates-as-britney.html,viewed on 16th December, 2006.

Friedman, I. (2006) 'Enough with Being Right; Let's Be Attractive', Jerusalem Report, 27th November, 2006, p. 48.

IDA Ireland (2006), in http://www.idaireland.com,viewed on 17th December, 2006.

Kotler, P. and Gertner, D. (2002) 'Country as brand, product, and beyond: A place marketing and brand management perspective', Journal of Brand Management, Vol. 9, pp. 249261.

Mishra, P. (2006) 'The myth of the new India', The New York Times, Op-Ed, 6th July, 2006.

Thinkquest (2006) 'A dollar a day: Finding solutions to poverty', in http://library.thinkquest.org/05aug/00282/over_world. htm,viewed on 11th December, 2006.

Ray, J. (2006). 'Defrosting Greenland's image, brand channel', in http://www.brandchannel.com/start1.asp?fa_id=333, viewed on 25th September, 2006.

Wikipedia (2006) Zimbabwe in http://en.wikipedia.org/wiki/ List_of_countries, viewed on 11th December, 2006.

Wines, M. (2006) ' "Outpost of tyranny," seeks tourists', The New York Times, 12th November 2006, in http://travel2. nytimes.com/2006/11/12/travel/12journeys.html?ref= travel,viewed on 12th November, 2006. 